\title{
Graduate Employability: A Gap between Perspectives - the Case of Croatia
}

\author{
Ljerka Sedlan Kőnig, Petra Mezulić Juric*, Tihana Koprivnjak \\ Faculty of Economics, Josip Juraj Strossmayer University in Osijek, Croatia
}

Copyright $\bigcirc 2016$ by authors, all rights reserved. Authors agree that this article remains permanently open access under the terms of the Creative Commons Attribution License 4.0 International License

\begin{abstract}
Awareness of the importance of higher education (HE) in the transition to a knowledge-based society is growing in Croatia and universities are increasingly required to produce employable graduates who have attributes, capabilities, knowledge and skills to work successfully, and are able to respond to the changing and complex needs of the labor market. This paper seeks to investigate and compare the importance of skills and attributes which enhance graduate employability, as well as their reception through higher education, from the perspective of employers, university teachers and senior students. The research has shown that students, university teachers and employers have a significantly different view regarding knowledge, skills and attributes important for employment, and the contribution of university teaching to the development of these skills, knowledge and attributes. In April 2015 a total of 340 surveys were collected (230 from senior students, 30 teachers at the Faculty of Economics in Osijek, and 80 employers from the region filled in the questionnaire). In analyzing data descriptive statistics and hypotheses testing are given. Mann-Whitney test is used to test the difference between two distributions, and Kruskal-Wallis ANOVA between three distributions.
\end{abstract}

Keywords Employability, Employers, University, Labor Market, Entrepreneurial Skills, Entrepreneurship Education

\section{Introduction}

The pressure on higher education institutions (HEI) to produce employable graduates has intensified following the recent economic recession (Crayford et.al. [1]). In the times of rising unemployment among highly educated, questions have been raised about the ability of graduates to meet the needs of the employers and the labor market. Business recruiters generally report seeking to hire well-rounded students who have not only technical knowledge and skills, but also behavioral ones (Rynes et.al. [2]). It has been confirmed that entrepreneurial mind-set positively influences future employment prospects and self-employment opportunities of graduates. Therefore, awareness of the importance of entrepreneurial higher education (HE) in the transition to a knowledge-based society is growing in Croatia and universities are increasingly required to produce employable graduates who have attributes, capabilities, knowledge and skills to work successfully, and are able to respond to the changing and complex needs of the employment environment. Skills such as leadership, communication, teambuilding, as well as entrepreneurial attributes such as determination, creativity, risk management and tolerance towards uncertainties, positive attitude towards change and initiative have become critical for hiring and promoting employees (Audibert and Jones [3]).

There is a growing need that HEI develop and evidence these qualities in graduates to help them qualify for the global economy (Gibb [4]), yet traditionally, the contract between university and student focuses on knowledge and skills transfer, not personal development (Gibb [5]). Increasingly, employers voice concern over the quality of graduates leaving universities, while teachers in HE feel that employers are not fully appreciative of what qualities and skills these graduates possess. Repeatedly the assumption is made that subject knowledge (usually learned well during $\mathrm{HE}$ ), is a must, but is not sufficient for employment. The employability skills, on the other hand, which complement subject knowledge and are critical in demonstrating the subject knowledge on the workplace, are rarely sufficiently developed through HE. Moreover, employers do not seem to clearly communicate their needs and expectations of graduates that they intend to hire. Even in situations where collaborative process between HEI and industry does exist, the structure of education has made it difficult to implement systemic changes (Richens[6]). Funding for soft skills training is being cut across work domains (Bedwell et.al. [7]). And this is also true in Croatia. It seems that if nothing is done to improve educational performance, the gap between skills and attributes needed by the industry and the skills and attributes received by students will continue to grow. This 
paper seeks to investigate and compare the perceptions of skills and attributes which enhance graduate employability, as well as survey to what extent they are acquired through HE, from the perspective of employers, senior students and university teachers.

\subsection{Literature Review}

The connection between higher education and employability is frequently a subject of discussion in academic community. There is a pressure on higher education, from both government and employers, to produce graduates who are employable in the sense that they have the knowledge, attributes, and capabilities to work successfully. Students start their studies with the expectation that they will acquire the knowledge, skills and abilities necessary to perform jobs and advance in their careers. Many apply for jobs and come to the job interview feeling that they deserve a job simply because they graduated. On the other hand, employers have an expectation that higher education will provide graduates with the employability skills required to perform their jobs (Bok [8]). In competitive economies, it is very unlikely that unprepared graduates will be successful in obtaining employment (Rosenberg et.al. [9]). Many young people are unemployed these days, among other things, because they lack non-technical skills and attributes that are considered as important as job specific skills to function in an employment environment (Conrad and Leigh [10]). Researchers (Etzkowitz [11], Rosenbaum [12], Carnevale et.al. [13]) have observed that employers valued work habits more important than academic skills, because they are considered to be the best predictors of job performance. Studies have also revealed that employers include soft skills, which can be transferred across occupations instead of being specialized, among their most important hiring criteria, and the most deficient skill received in higher education (Rosenberg et.al. [9]). Soft skills are particularly important in sectors where social relations with clients, customers and service users are of high importance for the delivery and quality of the work (Kyrieri and Roidou 2012 [14]). The National Employers Skills Survey 2003 [14] reported that employers regard shortages in soft skills, including communication, teamwork as far more crucial than technical skills. A good supply of skilled graduates is essential for national, economic and social wellbeing, and the failure to equip young people with employability skills has far reaching consequences (Cotton [15]). It is also argued that providing young people with skills for employability is an ethical responsibility of HEI.

The concept of employability is quite elusive, and generally it means having a set of skills, knowledge, understanding and personal attributes that make a person more likely to choose and secure occupations in which they can be satisfied and successful. SCANS report [16] found that students believed that employment skills were learned on the job, through participation in extracurricular activities, or simply by osmosis. Because organizations need to select interpersonally competent individuals who can successfully engage in interactions immediately upon hire, students must acquire effective interpersonal skills before entering the workforce (Bedwell et.al. [7]). In addition, Rosenbaum [12] noticed that if students do not learn basic employability skills before they are hired, they may not have the opportunity to learn them on the job, since employers may be reluctant to invest in training for these skills. Training and upskilling should be seen as an investment in a sustainable future rather than a cost to be minimized (Kyrieri and Roidou 2012 [14]). The situation in Croatia is similar as, according to Liderpress.hr, majority of employers $(63 \%)$ believe that their employees need communication or presentation skills, but only $40 \%$ are interested in investing in their education. In a 2010 report titled "Employability skills" [19], UK-based City \& Guilds Centre for Skills Development stated that employers are prepared to fund training to develop specific job-related skills, but employability skills represent personal qualities that are the individual graduate's responsibility.

Diverse authors (Carnevale et.al. [13], Nunan [20], Conrad and Leigh [10], Swiatek [21], Rosenbaum [12], Gibb [5], Yorke and Knigh [22], Bracey [23], Van Der Heijden et al. [24], Nasir et.al. [25], Fatoki [26], as well as SCANS repot [17] and DOTS model) agree that subject knowledge is not sufficient for acquiring, fulfilling, or creating of employment, but they determine what constitutes employability skills in different ways. Generally, employability skills are considered to include: knowledge, transferable skills, efficacy beliefs, personal qualities and entrepreneurial skills.

\subsection{Employability}

Employability is an issue of concern in many areas of the economy. It is extremely difficult to identify a single definition, as, among other things, it depends on the context and the implementation of the term. Among others, a definition can be found in the literature that defines employability as continuous fulfilling, acquiring or creating of work through the optimal use of competencies (Van Der Heijden et al. [24]). The term employability is used to mean a set of achievements that comprise skills, understanding and personal attributes (Yorke and Knight [22]) that make an individual more likely to gain and maintain initial employment, make transitions between jobs and roles, within the same organization, and the ability to obtain new employment, by being independent in the employment environment and able to manage employment transitions between organizations (Hillage and Polland [27]). Some authors have given their own interpretation of the term employability through a range of characteristics which it encompasses. So, Enhancing Student Employability Co-ordination Team (ESECT) founded by Higher Education Funding Council for England whose aim is to support the higher education sector in its effort to develop employable graduates, defines employability through the following phases: (1) getting a (graduate) job,(2) possession 
of vocational degree, (3) formal work experience, (4) good use of non-formal work experience and/or voluntary work, (5) possession of „key skills“ or such like, (6) skillful career planning and interview technique, (7) a mix of cognitive and non-cognitive achievements and representations (Yorke [28]). In addition, it is important to differentiate between employment and employability, where employment relates to the actual acquisition of a job, and employability to the capacity of a graduate to function in a job.

Higher education, or relevant work experience, do not guarantee employability (Yorke [28]). They certainly provide an opportunity to develop employability, but it actually derives from the experiences of students who have been involved in the education or practice. It is evident that employability represents a broad concept that includes three basic elements: it is demonstrated by a graduate actually obtaining a job, student's experience of HE (curricular and extracurricular activities), and possession of relevant achievements and potential (Yorke [28]). This concept, in addition to stressing the importance of formal learning and work experience, emphasizes the importance of involvement in extracurricular activities and voluntary work, which students can appreciate through involvement and work in, for instance, student associations and thus increase their competitiveness in the employment environment. Besides, employability is not a static category, but something that a person could develop throughout life, and this, in turn, denotes the importance and the necessary connection between the concept of employability and lifelong learning, i.e. the willingness to learn. Earlier conceptions that relied on lists of 'key generic skills' have given way to more nuanced approaches, which emphasize practical skills, understandings, personal attributes and metacognition (Giesel and Parker [29]).

The literature suggests two aspects of employability as: subject skills and transferable skills (also called soft skills). Transferable skills refer to certain personal traits of an individual, which can be taken from one job to the other, used within any profession and at any stage of one's career, while subject skills are more related to a particular field and profession (Cox and King [30]). Students usually leave university with good knowledge of the field they studied, i.e. subject skills. In today's challenging business environment the possession of subject skills alone is no longer sufficient to meeting employer requirements. Increasingly it is necessary to gain transferable skills which will enhance the prospects for employment (Cox and King [30]). Therefore, employability skills are often referred to as attributes of an employee, other than technical competence, that make them an asset to an employer (Buck and Barrick [31]).

\subsection{Dimensions of Employability Skills}

For the purpose of this study it is important to determine what constitutes employability skills. The SCANS report [17] very broadly defines dimensions of employability skills as: basic literacy and numeracy skills, critical thinking skills, leadership, management skills, interpersonal skills, information technology skills, systems thinking skills, and work ethic.

The DOTS model, designed by the Centre for Entrepreneurship at the University of Central Lancashire, UK, defines Decision learning (decision making skills), Opportunity awareness (knowing what work opportunities exist and what their requirements are), Transition learning (job searching and self-presenting skills) and Self-awareness (interest, abilities, values etc) (Watts [32]) as practical solutions to enhancing prospects of students.

The so-called USEM account of employability includes four interrelated factors that affect employability: subject understanding; skills; efficacy beliefs, students' self-theories and personal qualities; and metacognition (Yorke and Knight [22]). Subject understanding or „knowledge" is the key outcome of higher education, and is related to the discipline which is the topic area of study. Next, core skills and disciplinary area skills are developed as a product of participation in higher education. Generic skills, such as communication, teamwork and time-management skills, can support study in any discipline, and can potentially be transferred to a range of contexts in HE or in workplace (Bennett et.al. [33]). Skills, either core or generic (a core skill in one discipline can be considered generic in the other), constitute an important component of employability. Third, efficacy is defined as the disposition to see tasks as opportunities for learning rather than as performance-oriented opportunities to demonstrate competence (Yorke, Knight [22]). In addition to that, it should be noted that students should feel that they are able to make a difference. Metacognition is the last element of the USEM account, and refers to the capacity for self-regulation, and is defined as ,knowing about knowing". Self-awareness about the knowledge and the students' abilities is crucial.

Self-efficacy, self-confidence and self-esteem provide an essential link between knowledge, understanding, skills, experience, personal attributes and employability. Self-efficacy is seen as a belief that an individual has the capability in a particular situation, and self-confidence could be seen as the way this is projected to the outside world. An increase in self-efficacy will be reflected in the increase in demonstrated self-confidence. It could also be suggested that everything students do during their studies will impact on self-esteem, and it is through the development of high global self-esteem that employability is achieved (Dacre Pool and Sewell [34]). The belief in one's capability to succeed and the ability to project this belief to the outside world is important, but by achieving a high level of self-esteem, graduates will also become more realistic about their achievement and committed to life-long learning.

The motivator to enter HE is generally to study a specific discipline in depth, to gain a degree, to get a higher qualification and thus a good job. It is still true that the better qualified have far greater employment opportunities (Johnes [35]). 
Even though the subject-specific knowledge, understanding and skills are extremely important in many cases, these alone are unlikely to secure graduates occupations in which they will be satisfied and successful. In an Australian study, Nunan [20] indicated that employment should include generic employability skills, meaning that graduates are enterprising and show worker flexibility. Entrepreneurial skills are often understood as a part of personal learning and development, and as such are often discussed in the employability literature. Employers want graduates with relevant subject specific skills, knowledge and understanding, but in addition to this, they are looking for well-developed young people (Harvey et.al. [36]). An enterprising graduate, being innovative, creative, adaptable, and a willing learner, will be valued in any organization.

In conclusion, besides professional skills and knowledge graduates need transferable and entrepreneurial skills and therefore, universities have been encouraged to provide more substantial impact on developing and stimulating entrepreneurial knowledge, skills, attitudes and values through their programs.

\subsection{Entrepreneurship Education}

Entrepreneurship education programs provide individuals with the ability to recognize commercial opportunities (Jones and English [37]), foster entrepreneurial competences in every individual, and develop awareness of the benefits of entrepreneurship in the society. Such skills and knowledge are essential not only for starting, managing and growing a new business, but also for acquiring a job and managing one's professional carrier.

The way in which universities affect employability of their students varies from one institution to the other, so there is no ideal employability-oriented curriculum. However, the manual Embedding employability into the curriculum, explains the existence of several ideal types of adapting the curriculum, being: (1) employability through the whole curriculum, (2) employability in the core curriculum, (3) work based or work related learning incorporated as one of components within the curriculum, (4) employability related modules within the curriculum, and (5) work based or work related learning parallel with the curriculum. It is important to note that certain types can interlace and that there is a possibility of simultaneous application of several of them (Yorke and Knight [22]).

The availability of entrepreneurship programs in higher education is important for a number of reasons. First of all, by embracing entrepreneurship programs universities make the first step in the shift towards knowledge-based society. Furthermore, by including the entrepreneurial objective as the third component to their mission (hand in hand with research and education) universities assume an active role in regional business development. By having a strong focus on entrepreneurial activities universities fulfill their role at the heart of the Triple Helix model (Etzkowitz [11]), which encompasses their deep involvement in economic and social development. Finally, by offering education in entrepreneurship universities develop entrepreneurial attributes in their students.

A major goal of higher education (and not only higher education) should be to equip students with the intellectual tools, efficacy beliefs and intrinsic interest to educate themselves throughout their lifetime. Several researchers (Bracey [22], Rosenbaum [12], Carnevale et.al. [13]) have observed that employers described work habits as being more important than academic skills, as they are often considered to be the best predictors of job performance. A lot of research (in Dacre Pool and Sewell [8]) points out the work experience as something employers value greatly in graduates, as well as learning from experience in the world of work in order to develop key skills and attributes and enhance employability. Partnerships between employers and HEI are valuable in promoting work related learning and in improving the quality of such experiences.

Literature review on entrepreneurship education pedagogy affirms that, in order to increase the likelihood of effective entrepreneurship outcomes, entrepreneurship education should take the experience based learning approach. Rosenberg [9] cited Chester E. Finn, Jr. who argued that requiring teachers to focus on the test results in basic academic skills negatively affects students' abilities to develop other skills that are central to the nation's competitive advantage. With the main challenge being the creation of appropriate learning environment which reflects the life world of entrepreneurs, entrepreneurship educators have increasingly adopted experiential approaches (Gibb [5]). Learning through experience, which combines experience, perceptions, cognitions and behaviors, is seen as an innovative alternative to traditional teaching. It emphasizes the central role that experience plays in the learning process (Rae and Carswell [38]).

\section{Method}

Differences in the importance given to employability skills by graduates and employers according to their perceptions have been documented in literature (Swiatek [21], Davies [39], Lindsay [40]), but these differences have not been tested in transitional economies. Having identified various employability skills based on the literature (Conrad and Leigh [10], Dacre Pool [34], Gibb [4], Schultz [41], Nasir et.al. [25] Hopkins et.al. [42], Fatoki [26]) the authors set out to test several central assumptions in this study:

a) employers, students and teachers have different perceptions of skills and attributes which enhance graduate employability

b) there is a gap between skills and attributes valued by the employers, and the skills and attributes received by students during $\mathrm{HE}$

c) employability skills are rarely sufficiently developed through HE, and there is a growing need that HEI develop and evidence these qualities in graduates to help them qualify for achieving employability 
This study is the first of a series of papers that examines the attitudes of students, teachers and employers in Croatia regarding skills and attributes needed for obtaining and securing employment, and the extent to which those skills are received during studies. This paper is based on a research in which the perspectives of three distinct groups on skills and attributes that increase graduate employability were studied: teachers who design and teach the courses at the Faculty of Economics of Josip Juraj Strossmayer University in Osijek, senior students at the Faculty and employers from companies of all sizes from the region. A triangular design approach (Senge [43]) permitted studying the problem from multiple points of view, providing a more useful way of addressing the issue. This approach allows to contrast all three respondent groups and to determine whether any critical gaps exist in perspectives. Data was collected by means of self-administered questionnaire. Three surveys (one for each category of respondents: senior students, university teachers and employers) included 11 , 12 , and 22 questions, respectively, and measured 36 dimensions of graduate employability.

Each survey employed open and closed questions, as well as seven-point Likert scales as answers. Three questionnaires were piloted prior to distribution, and the survey instrument was validated by an independent panel to ensure that all the questions were understandable to the respondents. In April 2015 a total of 340 surveys were collected. In total 340 questionnaires were collected (230 from senior students, 30 teachers at the Faculty of Economics in Osijek, and 80 employers from the region filled in the questionnaire).

In analyzing data descriptive statistics and hypotheses testing are given. Mann-Whitney test is used to test the difference between two distributions, and Kruskal-Wallis ANOVA between three distributions.

\section{Results and Discussion}

Table 1 presents the means for each variable and the differences between respondent attitudes regarding the importance of the variables for employability by the three respondent groups. Although there is certain agreement in opinion among respondents in the survey, the study revealed considerable differences in perspectives between the respondent groups, with regard to skills and attributes needed for employability. Some of the key findings of the triangular model are indicated below.

As expected, all three groups value aggression, achievement in sport, sense of humor and attractive appearance as the least important in obtaining and securing a job. Interestingly, employers and students give little importance to grade point average (GPA) during studies (means 3.95 and 3.96 respectively), whereas teachers provide much higher value for it (5.30). The fact that as many as $98 \%$ of employers would rather employ a candidate with poorer GPA, if he /she had good communication skills, intelligence, discipline, the desire for achievement and work ethics, is also thought provoking. Employers do not give high mean scores to subject knowledge, usage of social networks, or public speaking skills. Practical experience is not assigned a high value either, although employers value application of knowledge. Later on in the survey, $88 \%$ of employers and $97 \%$ of students agree that during HE not enough attention is given to application of knowledge. Similarly, students do not consider subject knowledge important (rank 31), and rate critical thinking, usage of social networks and work ethics rather low in importance. Likewise, teachers rank work ethics and grade point average (GPA) during studies low (rank 30 and 28 of 36, respectively) in importance for employability, as well as independence (rank 31) and taking initiative (rank 26). Low ranking of work ethics particularly by teachers and students in this study is surprising. On the other hand, the results of this study compliment previous research which established that for performance in an employment environment, application of knowledge, non-technical skills and certain personal attributes are more important than subject knowledge.

All three groups value foreign language skills, solving problems, willingness to learn and IT usage highly. But the findings suggest that there are significant differences in the rankings given for employability skills and attributes by the respondent groups. Among selected employability skills, employers characterize problem solving, learning skills, and willingness to learn as the most important employability skills. Enthusiasm and motivation, intelligence and establishing and maintaining interpersonal contact also score high. Among the valuable skills employers also include application of acquired knowledge, IT usage and foreign language skills. These results indicate that employers in Croatia are looking for well-developed young people with a number of attributes as their future employees.

Similarly to employers, students also include problem solving skills and willingness to learn among the most important employability skills, but they value foreign language skills, IT usage and positive attitude towards change as critical, too. Surprisingly, in their rating, teachers give the highest rank to application of knowledge. In particular, of all respondents groups, it is teachers who give the highest means to application of knowledge (6.10). They also assess highly the importance of interpersonal relationships, willingness to learn, problem solving skills and IT usage. Interesting finding is also that, employers estimate the importance of learning skills much higher than practical experience or subject knowledge. Furthermore, subject knowledge is, by all respondent groups rated rather low in importance. Low rank for practical experience (rank 29) given by employers is surprising because it is widely agreed that graduates with work experience are more likely to secure employment than graduates without. 
Table 1. Estimation of importance of employability skills - comparison between employers, students and teachers

\begin{tabular}{|c|c|c|c|c|c|c|c|c|c|c|}
\hline \multirow{2}{*}{ Dimensions } & \multicolumn{3}{|c|}{ Employers } & \multicolumn{3}{|c|}{ Students } & \multicolumn{3}{|c|}{ Teachers } & \multirow{2}{*}{ p Value* } \\
\hline & Mean & Std.Dev. & Rank & Mean & Std.Dev. & Rank & Mean & Std.Dev. & Rank & \\
\hline Problem solving & 6.30 & 0.97 & 1 & 6.15 & 1.08 & 4 & 6.00 & 0.98 & 4 & 0.1823 \\
\hline Learning skills & 6.19 & 1.26 & 2 & 5.74 & 1.27 & 20 & 5.93 & 1.17 & 6 & 0.0018 \\
\hline Willingness to learn & 6.16 & 0.95 & 3 & 6.16 & 0.99 & 2 & 6.03 & 0.89 & 3 & 0.5633 \\
\hline Enthusiasm and motivation & 6.16 & 1.13 & 4 & 5.89 & 1.14 & 16 & 5.70 & 0.99 & 19 & 0.0162 \\
\hline Intelligence & 6.11 & 1.06 & 5 & 5.97 & 1.06 & 12 & 5.86 & 1.06 & 11 & 0.3321 \\
\hline $\begin{array}{l}\text { Establishing and maintaining } \\
\text { interpersonal contact }\end{array}$ & 6.09 & 0.94 & 6 & 5.87 & 1.18 & 17 & 6.07 & 0.88 & 2 & 0.4077 \\
\hline $\begin{array}{c}\text { Application of acquired } \\
\text { knowledge }\end{array}$ & 6.08 & 1.09 & 7 & 5.93 & 1.42 & 15 & 6.10 & 1.06 & 1 & 0.9938 \\
\hline IT usage & 6.08 & 1.04 & 8 & 6.16 & 0.99 & 3 & 5.93 & 0.83 & 5 & 0.1939 \\
\hline Foreign language & 6.04 & 1.07 & 9 & 6.25 & 1.15 & 1 & 5.93 & 0.91 & 7 & 0.0091 \\
\hline Diligence & 5.99 & 1.04 & 10 & 5.99 & 1.10 & 11 & 5.77 & 1.07 & 12 & 0.4522 \\
\hline Teamwork & 5.99 & 1.04 & 11 & 6.03 & 1.16 & 8 & 5.77 & 0.90 & 13 & 0.1272 \\
\hline $\begin{array}{l}\text { Thinking "outside the box" } \\
\text { and innovativeness }\end{array}$ & 5.98 & 1.12 & 12 & 5.99 & 1.27 & 10 & 5.73 & 1.05 & 17 & 0.1892 \\
\hline Desire for achievement & 5.95 & 1.11 & 13 & 5.93 & 1.19 & 14 & 5.57 & 1.19 & 22 & 0.1303 \\
\hline $\begin{array}{l}\text { Positive attitude towards } \\
\text { change }\end{array}$ & 5.94 & 1.04 & 14 & 6.12 & 0.97 & 5 & 5.90 & 0.80 & 10 & 0.1244 \\
\hline Written communication & 5.91 & 0.94 & 15 & 6.06 & 1.09 & 7 & 5.67 & 0.96 & 20 & 0.0162 \\
\hline Opportunity recognition & 5.89 & 1.30 & 16 & 5.77 & 1.28 & 19 & 5.70 & 1.12 & 18 & 0.4477 \\
\hline Discipline & 5.75 & 1.01 & 17 & 5.64 & 1.15 & 23 & 5.73 & 1.01 & 15 & 0.8954 \\
\hline Work ethics & 5.73 & 1.51 & 18 & 5.38 & 1.45 & 28 & 5.17 & 1.42 & 30 & 0.0422 \\
\hline Self-confidence & 5.73 & 1.08 & 19 & 5.94 & 1.17 & 13 & 5.90 & 0.80 & 8 & 0.1123 \\
\hline Taking initiative & 5.71 & 1.19 & 20 & 5.54 & 1.15 & 25 & 5.40 & 1.13 & 26 & 0.2015 \\
\hline Negotiation skills & 5.65 & 1.29 & 21 & 6.00 & 1.06 & 9 & 5.63 & 1.03 & 21 & 0.0266 \\
\hline Work under pressure & 5.65 & 1.20 & 22 & 5.60 & 1.30 & 24 & 5.38 & 1.37 & 27 & 0.5978 \\
\hline Independence & 5.54 & 1.19 & 23 & 5.68 & 1.06 & 21 & 5.13 & 1.20 & 31 & 0.0629 \\
\hline $\begin{array}{l}\text { Making judgments on basis of } \\
\text { limited information }\end{array}$ & 5.49 & 1.36 & 24 & 5.67 & 1.18 & 22 & 5.77 & 1.14 & 14 & 0.5891 \\
\hline Critical thinking & 5.45 & 1.20 & 25 & 5.20 & 1.27 & 30 & 5.73 & 1.11 & 16 & 0.0270 \\
\hline Persuasion & 5.41 & 1.17 & 26 & 5.86 & 1.21 & 18 & 5.40 & 1.13 & 25 & 0.0003 \\
\hline $\begin{array}{c}\text { Strong orientation to } \\
\text { achievement }\end{array}$ & 5.34 & 1.22 & 27 & 5.41 & 1.13 & 27 & 5.23 & 1.43 & 29 & 0.8980 \\
\hline Public speaking & 5.21 & 1.37 & 28 & 6.09 & 1.18 & 6 & 5.43 & 1.04 & 24 & 0.0000 \\
\hline Practical experience & 5.10 & 1.61 & 29 & 5.49 & 1.46 & 26 & 5.90 & 1.18 & 9 & 0.0363 \\
\hline Subject knowledge & 4.86 & 1.37 & 30 & 4.94 & 1.34 & 31 & 5.43 & 1.01 & 23 & 0.1505 \\
\hline Usage of social networks & 4.70 & 1.59 & 31 & 5.24 & 1.34 & 29 & 4.93 & 1.11 & 32 & 0.0146 \\
\hline Sense of humor & 4.61 & 1.45 & 32 & 4.16 & 1.45 & 32 & 4.73 & 0.94 & 33 & 0.0129 \\
\hline Grade point average (GPA) & 3.95 & 1.66 & 33 & 3.96 & 1.56 & 33 & 5.30 & 1.21 & 28 & 0.0000 \\
\hline Attractive appearance & 3.29 & 1.62 & 34 & 3.72 & 1.78 & 34 & 3.70 & 1.60 & 34 & 0.1978 \\
\hline Achievement in sport & 3.28 & 1.55 & 35 & 3.07 & 1.40 & 35 & 3.27 & 1.48 & 36 & 0.4263 \\
\hline Aggression & 2.89 & 1.52 & 36 & 3.01 & 1.56 & 36 & 3.57 & 1.57 & 35 & 0.1170 \\
\hline
\end{tabular}

*p-value is given for Kruskal-Wallis ANOVA test

At level of significance of $5 \%$, differences in importance of some skills and attributes between three groups can be seen, in particular for persuasion, written communication, critical thinking, public speaking and ethics. Significant gaps in values are also observed for learning skills, as employers rank them much higher (6.19) than teachers (5.93) or students (5.74); foreign language skills, ranked most important by students (6.25), much less so by employers (6.04) and teachers (5.93). Whereas public speaking skills are thought highly of by students (6.09), they score much less by teachers (5.43) and employers (5.21). Significant differences are observed also in rather low scores for team work by teachers (5.79) and employers
(5.80) as opposed to a higher score by students (6.11).

Interestingly, typical entrepreneurial attributes such as problem solving, making judgments on the basis of limited information, taking initiative, thinking out of the box, determination to be independent, strong orientation to achievement, work under pressure and positive attitude towards change are considered by all three groups rather unimportant for employment, with the exception of problem solving skills. Initiative, achievement and independence are particularly low. Remarkably, low values, by all groups (teachers: 5.23; employers: 5.34; students: 5.41) are attached to strong orientation to achievement. Of the three groups, only students set a high value (6.12) on positive 
attitude towards change, and employers particularly value enthusiasm and motivation (6.16). These results are surprising because literature (Audibert and Jones [3]) asserts that entrepreneurial attributes have become critical for hiring and promoting employees, and entrepreneurial, innovative, creative and adaptable employees are widely considered valuable for any organization. Moreover, the results are disturbing because entrepreneurship is recognized as one of the key competences for life-long learning (EU Parliament [44]). It seems that in Croatia employers, university teachers, as well as graduates themselves are unaware of what employability skills are, much less how to acquire them.
Table 2 depicts the perception of HE contribution to development of employability skills. As can be seen, the three respondent groups agree that HE contributes the least to gaining sense of humor, development of general intelligence, aggression and achievement in sport, and the most to teamwork, willingness to learn and use of IT. Additionally, employers point out a significant contribution of teaching at HEI to acquisition of foreign language skills (4.68), written communication (4.58) and discipline (4.54); teachers to public speaking skills (5.63), acquisition of subject knowledge (5.63), learning skills (5.07), and interpersonal relationships (4.97)

Table 2. Estimation of HE contribution to development of employability skills - comparison between employers, students and teachers

\begin{tabular}{|c|c|c|c|c|c|c|c|c|c|c|}
\hline \multirow{2}{*}{ Dimensions } & \multicolumn{3}{|c|}{ Employers } & \multicolumn{3}{|c|}{ Students } & \multicolumn{3}{|c|}{ Teachers } & \multirow{2}{*}{ p Value } \\
\hline & Mean & Std.Dev. & Rank & Mean & Std.Dev. & Rank & Mean & Std.Dev. & Rank & \\
\hline Subject knowledge & 4.91 & 1.54 & 1 & 4.65 & 1.36 & 10 & 5.63 & 0.85 & 2 & 0.0004 \\
\hline IT usage & 4.87 & 1.54 & 2 & 5.03 & 1.45 & 3 & 5.37 & 1.13 & 3 & 0.4577 \\
\hline Foreign language & 4.68 & 1.61 & 3 & 4.51 & 1.69 & 13 & 4.93 & 1.39 & 9 & 0.3940 \\
\hline Teamwork & 4.68 & 1.61 & 4 & 5.53 & 1.29 & 1 & 5.33 & 1.09 & 4 & 0.0001 \\
\hline Willingness to learn & 4.59 & 1.69 & 5 & 4.84 & 1.57 & 7 & 5.20 & 0.96 & 5 & 0.3123 \\
\hline Written communication & 4.58 & 1.68 & 6 & 4.99 & 1.47 & 4 & 4.47 & 1.36 & 20 & 0.0394 \\
\hline Discipline & 4.54 & 1.44 & 7 & 4.27 & 1.51 & 17 & 4.67 & 0.99 & 16 & 0.2177 \\
\hline Public speaking & 4.51 & 1.57 & 8 & 5.49 & 1.43 & 2 & 5.63 & 1.07 & 1 & 0.0000 \\
\hline Diligence & 4.44 & 1.54 & 9 & 4.52 & 1.57 & 12 & 4.83 & 0.99 & 12 & 0.7490 \\
\hline Work under pressure & 4.39 & 1.50 & 10 & 4.87 & 1.67 & 6 & 4.93 & 1.26 & 10 & 0.0647 \\
\hline $\begin{array}{c}\text { Establishing and maintaining } \\
\text { interpersonal contact }\end{array}$ & 4.25 & 1.70 & 11 & 4.72 & 1.33 & 8 & 4.97 & 1.19 & 8 & 0.0559 \\
\hline Learning skills & 4.16 & 1.80 & 12 & 4.15 & 1.67 & 25 & 5.07 & 1.17 & 7 & 0.0180 \\
\hline Problem solving & 4.14 & 1.56 & 13 & 4.46 & 1.51 & 14 & 4.60 & 1.10 & 18 & 0.3163 \\
\hline Positive attitude towards change & 4.13 & 1.67 & 14 & 4.89 & 1.58 & 5 & 4.77 & 1.01 & 14 & 0.0015 \\
\hline Independence & 3.95 & 1.73 & 15 & 4.40 & 1.44 & 15 & 4.80 & 1.00 & 13 & 0.0791 \\
\hline Usage of social networks & 3.86 & 1.74 & 16 & 4.67 & 1.63 & 9 & 5.17 & 1.34 & 6 & 0.0002 \\
\hline Self-confidence & 3.86 & 1.62 & 17 & 4.23 & 1.48 & 19 & 4.40 & 1.07 & 24 & 0.1541 \\
\hline Strong orientation to achievement & 3.85 & 1.52 & 18 & 4.17 & 1.50 & 23 & 4.50 & 1.09 & 19 & 0.1628 \\
\hline Critical thinking & 3.85 & 1.60 & 19 & 4.08 & 1.50 & 27 & 4.30 & 1.33 & 28 & 0.3081 \\
\hline Desire for achievement & 3.82 & 1.63 & 20 & 4.62 & 1.65 & 11 & 4.87 & 1.22 & 11 & 0.0008 \\
\hline Negotiation skills & 3.81 & 1.49 & 21 & 4.25 & 1.59 & 18 & 4.77 & 1.10 & 15 & 0.0098 \\
\hline Work ethics & 3.80 & 1.70 & 22 & 4.16 & 1.70 & 24 & 4.30 & 1.29 & 30 & 0.2448 \\
\hline Persuasion & 3.65 & 1.51 & 23 & 4.10 & 1.42 & 26 & 4.30 & 1.15 & 29 & 0.0490 \\
\hline Application of acquired knowledge & 3.65 & 1.49 & 24 & 3.63 & 1.68 & 31 & 4.63 & 1.22 & 17 & 0.0029 \\
\hline $\begin{array}{l}\text { Thinking "outside the box" and } \\
\text { innovativeness }\end{array}$ & 3.61 & 1.70 & 25 & 4.17 & 1.59 & 22 & 4.40 & 1.00 & 25 & 0.0228 \\
\hline Enthusiasm and motivation & 3.61 & 1.61 & 26 & 4.22 & 1.62 & 20 & 4.43 & 1.22 & 22 & 0.0083 \\
\hline Taking initiative & 3.58 & 1.49 & 27 & 4.08 & 1.44 & 28 & 4.20 & 1.21 & 31 & 0.0276 \\
\hline $\begin{array}{c}\text { Making judgments on basis of } \\
\text { limited information }\end{array}$ & 3.58 & 1.57 & 28 & 4.21 & 1.52 & 21 & 4.33 & 0.96 & 27 & 0.0091 \\
\hline Practical experience & 3.57 & 1.79 & 29 & 3.67 & 1.89 & 30 & 4.43 & 1.36 & 23 & 0.0557 \\
\hline Intelligence & 3.46 & 1.71 & 30 & 3.96 & 1.70 & 29 & 4.38 & 1.35 & 26 & 0.0133 \\
\hline Opportunity recognition & 3.44 & 1.50 & 31 & 4.30 & 1.49 & 16 & 4.43 & 1.10 & 21 & 0.0000 \\
\hline Aggression & 2.67 & 1.64 & 32 & 2.45 & 1.66 & 33 & 2.62 & 1.54 & 34 & 0.3393 \\
\hline Sense of humor & 2.67 & 1.53 & 33 & 2.57 & 1.52 & 32 & 2.90 & 1.58 & 33 & 0.4900 \\
\hline Achievement in sport & 2.54 & 1.43 & 34 & 2.31 & 1.42 & 34 & 3.40 & 1.85 & 32 & 0.0036 \\
\hline
\end{tabular}

*p-value is given for Kruskal-Wallis ANOVA test 
Students rate the contribution to public speaking skills (5.49) highly, and add significant contribution of teaching to written communication (4.99), positive attitude to changes (4.89) and work under pressure (4.87).

On the other hand, employers, teachers and students agree that HE contributes little to taking initiative and gaining practical experience. The opinion of university teachers is significantly different from that of employers, in particular for negotiation, general intelligence and opportunity recognition. University teachers value contribution to these as very high, whereas employers value it as the lowest. It is interesting that, in general, university teachers value the contribution of teaching at the Faculty of Economics to the acquisition of employability skills with higher grades than students or employers. In this study, employers seem to share the opinion that students in general leave faculty with good knowledge of the field studied, but employers do not seem to consider subject knowledge critical for good performance in the employment environment. In their opinion, other dimensions such as learning skills and willingness to learn as well as enthusiasm and motivation are much more important for employment.

In addition, $86 \%$ of employers and $75 \%$ of students agree that senior students lack soft skills. This is in line with previous research (Rosenberg et.al. [9]) which demonstrated that soft skills are the most deficient skills received in HE. in summary, there is (except for IT usage and team work), much variation across these variables for respondents groups. Some of the interesting differences include the following. Teachers and employers believe that HE significantly contributes to gaining subject knowledge, but students agree with that in lesser degree. Also, students and especially teachers believe that teaching at the Faculty of Economics contributes significantly to the improvement in public speaking skills, but the employers do not share that opinion. Interestingly, employers value the contribution to foreign language skills highly, but students and teachers do not share the same view. Students and employers are not satisfied with the impact of HE in application of knowledge. In addition, employers set a low value on the contribution of HE to enthusiasm, desire to achievement, ability to see opportunities, negotiation skills, use of social networks, whereas teachers and students appreciate the impact much more.

The presented results show that there is a lot of disagreement between respondent groups regarding HE contribution to development of employability skills. Overall, employers assess the contribution of HE to development of employability skills with the lowest values, although they believe the role of HE in increasing student employability is very important. Actually, all three groups estimated the role of $\mathrm{HE}$ in this as very important (73\% of employers, $52 \%$ teachers and $49 \%$ students). All three groups of respondents agree that not enough attention is paid to the application of acquired knowledge, and that senior students lack soft skills. They all share the opinion that cooperation between faculties and industry is the crucial factor for increasing students' employability and $88 \%$ of employers would gladly take part in designing the curriculum for certain courses.

The impact of HE on entrepreneurial skills (problem solving, making judgments on the basis of limited information, taking initiative, thinking out of the box, determination to be independent, strong orientation to achievement, work under pressure and positive attitude towards change) is in general assessed by all three groups of respondents, especially teachers, as rather low. Contribution of HE to work under pressure and positive attitude towards change, of all entrepreneurial skills hold the highest means. Additionally, employers order problem solving, positive attitude towards change, determination to be independent and desire to achievement among entrepreneurial skills which are sufficiently developed during HE. Students seem most satisfied with the contribution of teaching at the Faculty of Economics to development of desire to achieve, problem solving, determination to be independent and opportunities recognition. Teachers, on the other hand, appreciate greatly the contribution of teaching to desire to achieve, determination to be independent and problem solving. In response to the need for more employable graduates, universities in Croatia are increasingly affirming entrepreneurial education as a core part of their curriculum, but these efforts are not enough as more attention has to paid to effective methods of teaching, as the results signal that teaching at Faculty of Economics weakly contributes to development of entrepreneurial skills.

Tables 3, 4, and 5 present the gap between means for importance of employability skills and their acquisition during studies. Considerable differences have been observed concerning the importance of employability skills and the contribution of HE to development of these skills. This corresponds with the findings in previous literature (Davies [39], Lindsay [40]). In general, means for importance of employability skills are significantly higher than the means for HE contribution to their development. 
Table 3. Differences between estimation of importance of employability skills and HE contribution to their development - employers perspective

\begin{tabular}{|c|c|c|c|}
\hline \multirow{2}{*}{ Dimensions } & Importance & Contribution & \multirow{2}{*}{$p$ Value* } \\
\hline & Mean & Mean & \\
\hline Subject knowledge & 4.86 & 4.91 & 0.609218 \\
\hline Application of knowledge & 6.08 & 3.65 & 0.000000 \\
\hline Learning skills & 6.19 & 4.16 & 0.000000 \\
\hline Establishing and maintaining interpersonal contact & 6.09 & 4.25 & 0.000000 \\
\hline Usage of social networks & 4.70 & 3.86 & 0.004411 \\
\hline Teamwork & 5.99 & 4.68 & 0.000000 \\
\hline Persuasion & 5.41 & 3.65 & 0.000000 \\
\hline Written communication & 5.91 & 4.58 & 0.000000 \\
\hline Foreign languages & 6.04 & 4.68 & 0.000000 \\
\hline Sense of humor & 4.61 & 2.67 & 0.000000 \\
\hline Critical thinking & 5.45 & 3.85 & 0.000000 \\
\hline Negotiation skills & 5.65 & 3.81 & 0.000000 \\
\hline Public speaking & 5.21 & 4.51 & 0.004667 \\
\hline Problem solving & 6.30 & 4.14 & 0.000000 \\
\hline $\begin{array}{c}\text { Intelligence } \\
\end{array}$ & 6.11 & 3.46 & 0.000000 \\
\hline Making judgments on basis of limited information & 5.49 & 3.58 & 0.000000 \\
\hline Thinking out of the box and innovativeness & 5.98 & 3.61 & 0.000000 \\
\hline Opportunity recognition & 5.89 & 3.44 & 0.000000 \\
\hline Work ethics & 5.73 & 3.80 & 0.000000 \\
\hline Enthusiasm and motivation & 6.16 & 3.61 & 0.000000 \\
\hline Desire for achievement & 5.95 & 3.82 & 0.000000 \\
\hline Aggression & 2.89 & 2.67 & 0.267325 \\
\hline Taking initiative & 5.71 & 3.58 & 0.000000 \\
\hline Strong orientation to achievement & 5.34 & 3.85 & 0.000000 \\
\hline Independence & 5.54 & 3.95 & 0.000000 \\
\hline IT usage & 6.08 & 4.87 & 0.000000 \\
\hline Self-confidence & 5.73 & 3.86 & 0.000000 \\
\hline Achievement in sport & 3.28 & 2.54 & 0.003173 \\
\hline Discipline & 5.75 & 4.54 & 0.000000 \\
\hline Diligence & 5.99 & 4.44 & 0.000000 \\
\hline Willingness to work & 6.16 & 4.59 & 0.000000 \\
\hline Work under pressure & 5.65 & 4.39 & 0.000000 \\
\hline Positive attitude towards change & 5.94 & 4.13 & 0.000000 \\
\hline Practical experience & 5.10 & 3.57 & 0.000000 \\
\hline
\end{tabular}

*p-value is given for Mann-Whitney test

Based on these findings a conclusion can be made that respondents in this study perceive the importance of employability skills, but do not believe that teaching at the Faculty of Economics contributes sufficiently to the development of employability skills in students. The differences for two issues are the largest in the case of grades given by employers, and the least significant by teachers. Values for almost all employability skills given by employers are significantly higher than the values given for HE contribution to their development (See Table 3). This is contrary to a similar study (Wickramsinghe and Lasantha [45]) which identified a skill gap only in problem solving skills. The most dramatic differences can be observed in the categories of general intelligence, enthusiasm, application of acquired knowledge, opportunities recognition, thinking out of the box, taking initiative and desire to achieve, which are interestingly, all entrepreneurial attributes. Based on these results, a conclusion can be made that employers are not satisfied with what HEI deliver to the labor market in Croatia.

In the media and elsewhere employers repeatedly voice their concern about the quality of graduates that exit HE. Therefore, teachers should focus not only on the acquisition of subject knowledge, but to the application of acquired knowledge and development of employability skills and attributes.

Substantial differences in importance of employability skills and the contribution of teaching at the Faculty of Economics to development of these skills can also be observed in case of students (See Table 4), especially for general intelligence, negotiation skills, thinking out of the box and power of persuasion. 
Table 4. Differences between estimation of importance of employability skills and HE contribution to their development - students perspective

\begin{tabular}{|c|c|c|c|}
\hline \multirow{2}{*}{ Dimensions } & Importance & Contribution & \multirow{2}{*}{$p$ Value* } \\
\hline & Mean & Mean & \\
\hline Subject knowledge & 4.94 & 4.65 & 0.02051 \\
\hline Application of knowledge & 5.93 & 3.63 & 0.00000 \\
\hline Learning skills & 5.74 & 4.15 & 0.00000 \\
\hline Establishing and maintaining interpersonal contact & 5.87 & 4.72 & 0.00000 \\
\hline Usage of social networks & 5.24 & 4.67 & 0.00044 \\
\hline Teamwork & 6.03 & 5.53 & 0.00001 \\
\hline Persuasion & 5.86 & 4.10 & 0.00000 \\
\hline Written communication & 6.06 & 4.99 & 0.00000 \\
\hline Foreign languages & 6.25 & 4.51 & 0.00000 \\
\hline Sense of humor & 4.16 & 2.57 & 0.00000 \\
\hline Critical thinking & 5.20 & 4.08 & 0.00000 \\
\hline Negotiation skills & 6.00 & 4.25 & 0.00000 \\
\hline Public speaking & 6.09 & 5.49 & 0.00000 \\
\hline Problem solving & 6.15 & 4.46 & 0.00000 \\
\hline Intelligence & 5.97 & 3.96 & 0.00000 \\
\hline Making judgments on basis of limited information & 5.67 & 4.21 & 0.00000 \\
\hline Thinking out of the box and innovativeness & 5.99 & 4.17 & 0.00000 \\
\hline Opportunity recognition & 5.77 & 4.30 & 0.00000 \\
\hline Work ethics & 5.38 & 4.16 & 0.00000 \\
\hline Enthusiasm and motivation & 5.89 & 4.22 & 0.00000 \\
\hline Desire for achievement & 5.93 & 4.62 & 0.00000 \\
\hline Aggression & 3.01 & 2.45 & 0.00001 \\
\hline Making initiative & 5.54 & 4.08 & 0.00000 \\
\hline Strong orientation to achievement & 5.41 & 4.17 & 0.00000 \\
\hline Independence & 5.68 & 4.40 & 0.00000 \\
\hline IT usage & 6.16 & 5.03 & 0.00000 \\
\hline Self-confidence & 5.94 & 4.23 & 0.00000 \\
\hline Achievement in sport & 3.07 & 2.31 & 0.00000 \\
\hline Discipline & 5.64 & 4.27 & 0.00000 \\
\hline Diligence & 5.99 & 4.52 & 0.00000 \\
\hline Willingness to work & 6.16 & 4.84 & 0.00000 \\
\hline Work under pressure & 5.60 & 4.87 & 0.00000 \\
\hline Positive attitude towards change & 6.12 & 4.89 & 0.00000 \\
\hline Practical experience & 5.49 & 3.67 & 0.00000 \\
\hline
\end{tabular}

*p-value is given for Mann-Whitney test

As expected, with teachers, differences between importance of skills and HE contribution to development are the least notable (See Table 5). In some cases, for example for usage of social networks and public speaking skills, HE contribution is rated higher than the importance. Interestingly, the mean given by teachers to HE contribution to acquisition of subject knowledge (5.63) is higher than the mean for importance of subject knowledge (5.43) in securing employment. 
Table 5. Differences between estimation of importance of employability skills and HE contribution to their development - teachers perspective

\begin{tabular}{|c|c|c|c|}
\hline \multirow{2}{*}{ Dimensions } & Importance & Contribution & \multirow{2}{*}{ p Value* } \\
\hline & Mean & Mean & \\
\hline Subject knowledge & 5.43 & 5.63 & 0.397112 \\
\hline Application of knowledge & 6.10 & 4.63 & 0.000016 \\
\hline Learning skills & 5.93 & 5.07 & 0.007074 \\
\hline Establishing and maintaining interpersonal contact & 6.07 & 4.97 & 0.000223 \\
\hline Usage of social networks & 4.93 & 5.17 & 0.542452 \\
\hline Teamwork & 5.77 & 5.33 & 0.126019 \\
\hline Persuasion & 5.40 & 4.30 & 0.000220 \\
\hline Written communication & 5.67 & 4.47 & 0.000367 \\
\hline Foreign languages & 5.93 & 4.93 & 0.003016 \\
\hline Sense of humor & 4.73 & 2.90 & 0.000020 \\
\hline Critical thinking & 5.73 & 4.30 & 0.000016 \\
\hline Negotiation skills & 5.63 & 4.77 & 0.003117 \\
\hline Public speaking & 5.43 & 5.63 & 0.435879 \\
\hline Problem solving & 6.00 & 4.60 & 0.000012 \\
\hline Intelligence & 5.86 & 4.38 & 0.000031 \\
\hline Making judgments on basis of limited information & 5.77 & 4.33 & 0.000009 \\
\hline Thinking out of the box and innovativeness & 5.73 & 4.40 & 0.000022 \\
\hline Opportunity recognition & 5.70 & 4.43 & 0.000040 \\
\hline Work ethics & 5.17 & 4.30 & 0.022710 \\
\hline Enthusiasm and motivation & 5.70 & 4.43 & 0.000098 \\
\hline Desire for achievement & 5.57 & 4.87 & 0.012716 \\
\hline Aggression & 3.57 & 2.62 & 0.022466 \\
\hline Taking initiative & 5.40 & 4.20 & 0.000461 \\
\hline Strong orientation to achievement & 5.23 & 4.50 & 0.016809 \\
\hline Independence & 5.13 & 4.80 & 0.128985 \\
\hline IT usage & 5.93 & 5.37 & 0.038096 \\
\hline Self-confidence & 5.90 & 4.40 & 0.000001 \\
\hline Achievement in sport & 3.27 & 3.40 & 0.874101 \\
\hline Discipline & 5.73 & 4.67 & 0.000275 \\
\hline Diligence & 5.77 & 4.83 & 0.000944 \\
\hline Willingness to work & 6.03 & 5.20 & 0.001798 \\
\hline Work under pressure & 5.38 & 4.93 & 0.074065 \\
\hline Positive attitude towards change & 5.90 & 4.77 & 0.000058 \\
\hline Practical experience & 5.90 & 4.43 & 0.000028 \\
\hline
\end{tabular}

*p-value is given for Mann-Whitney test

In conclusion, students, university teachers and employers adopt different perspectives on knowledge, skills and attributes important for employment and value the contribution of HE to the development of these skills, knowledge and attributes differently, which has implications for improving the curriculum, planning courses and managing graduates careers. We strongly believe that employers' opinion makes the difference, and therefore HEI, teachers and students have to be aware of what employers expect, and tailor the courses and choose methods of teaching based on that. 


\section{Conclusions}

This study has shown that employers, students and teachers have different perceptions of skills and attributes which enhance graduate employability. As collaboration is the foundation of business operations, executives consistently rank interpersonal skills as a critical competency for a successful workforce (Bedwell et.al. [45]). Our research proved the importance of interpersonal skills, but they were not ranked as high in importance as expected. According to this study, employers value problem solving skills, learning skills, willingness to learn, as well as enthusiasm and intelligence as the most important employability skills. They value the contribution of teaching at Faculty of Economics to acquisition of subject knowledge, IT usage and teamwork as substantial, and to development of enthusiasm and general intelligence, as well as to acquisition of entrepreneurial attributes as insufficient. As expected, employers assess the contribution of $\mathrm{HE}$ teaching to development of entrepreneurial skills as rather low, but the fact that employers in our study do not recognize entrepreneurial skills particularly as important for enhancing employability is surprising. This leads us to the conclusion that they are not fully aware of what employable graduates attributes actually are. Furthermore, there is a significant gap between skills and attributes valued by the employers, and the skills and attributes received by students during HE. In summary, the findings indicate that skills and attributes which employers expect graduates to bring to the workplace, such as intelligence, enthusiasm and motivation, application of knowledge, problem solving and learning skills are weakly developed during HE. This study highlights the growing need that faculties put emphasis upon skills development based upon employers' priorities, as well as monitor the realized effects of teaching at HEI in increasing the employability of students.

Students have expectations that their university education will prepare them for their future career. They should recognize the need to develop a strong curriculum vitae, based on a blend of subject knowledge, skills and attributes, and higher educational institutions need to ensure that their graduates possess employability skills that employers expect them to possess.

Obviously, employability skills are desired to be taught during degree programs and therefore curriculum change is needed. Where, to what extent and how they are to be included in the curriculum is beyond the scope of this study. On the other hand, higher education institutions cannot be expected to provide undergraduates with completely and fully developed skills for future employment. It is important to point out that teachers, employers and students should be equally responsible for skills development. In order to develop skills that employers value highly, students need practical work training through internships, and in order to assist their students in that and build their own competitiveness, universities should develop strong partnerships with employers. Students should additionally be encouraged to participate in tasks in HE that can improve their employability skills by encouraging proactivity in students and their participation in extra-curricular activities. Senior students should take care of their skills levels and employers' priorities well in advance (during senior years of studying) in order to develop them in time, i.e. before looking for the job. We agree with Kyrieri and Roidou (2012 [14]) that only workers who have access to comprehensible information about the job markets and their opportunities can decide, for example, to undertake further training or relocate to a region where their qualifications' profiles are in demand and well rewarded

Education and labor market are closely interconnected because, from the systems perspective, the output/final product of higher education presents the intake of employment environment. If in a business relationship a supplier has to cater for customers' needs, then this should be equally true for the relationship between higher education and labor market. If there is little or no communication between the two, the quality and the type of the product will be inadequate. It is a good employability that students, employers and teachers should be looking for and it is important to increase employability in line with education attainment.

Although the initial purpose of the survey was to assess the usefulness of survey methodology as a means of assessing the importance of particular skills and attributes for graduate employability, the research addressed a number of interesting questions related to the importance of certain skills and attributes for increasing employability. Also, the triangular approach used in this study adds value to the existing literature on graduate employability. Measuring the importance of certain skills and attributes for employment from three sides validates the existence of the gap and the differences in perspectives among students, teachers at the faculty and employers.

The research is not exempt from limitations as it was limited to students and teachers at Faculty of Economics in Osijek, Croatia. It is suggested that further studies need to be conducted to determine whether differences in attitudes exist in regard to other faculties of the university, and to compare the responses of senior students and teachers from different universities. Also, a post hoc analysis is needed to test further the observed differences. An idea for additional research is to investigate how the differences fluctuate according to the changes made in the labor market and how employability skills could better match labor shortages.

\section{REFERENCES}

[1] Crayford, J., Fearon, C., McLaughlin, H., \& van Vuuren, W. 2012. Affirming entrepreneurial education: learning, employability and personal development. Industrial and Commercial Training. 44(4): 187-193.

[2] Rynes, S. L., Trank, C. Q., Lawson, A. M., \& Ilies, R. 2003. 
Behavioral coursework in business education: Growing evidence of a legitimacy crisis. Academy of Management Learning \& Education. 2(3): 269-283.

[3] Audibert, G. \& Jones, M. 2002. The Softer Side. Advisor Today. 97(2): 72

[4] Gibb, A. 2008. Entrepreneurship and enterprise education in schools and colleges: insights from UK practice. International Journal of Entrepreneurship Education. 6(2): 48.

[5] Gibb, A. 2002. In pursuit of a new entrepreneurship paradigm for learning: creative destruction, new values, new ways of doing things and new combinations of knowledge. International Journal of Management Reviews. 4(3): 233-269.

[6] Richens, G. (1999, December 12-15). Perceptions of southern Nevada employers regarding the importance of SCANS workplace basic skills. Annual Meeting of the Association for Career and Technical Education. Orlando, FL.

[7] Bedwell, W. L., Fiore, S. M., \& Salas, E. 2014. Developing the future workforce: An approach for integrating interpersonal skills into the MBA classroom. Academy of Management Learning \& Education. 13(2): 171-186.

[8] Bok, D. 2006 Our Underachieving Colleges. Princeton University Press, Princeton, NJ.

[9] Rosenberg, S., Heimler, R., \& Morote, E. S. (2012). Basic employability skills: a triangular design approach. Education+ Training, 54(1), 7-20.

[10] Conrad, C.A. \& Leigh, W.A. 1999. Soft skills: Bridge or barrier to employment? Focus, 27(1): 5-6.

[11] Etzkowitz, H. 2010. The triple helix: university-industry-government innovation in action. Routledge.

[12] Rosenbaum, J. 2002. Beyond Empty Promises: Policies to Improve Transitions into College and Jobs. Office of Vocational and Adult Education, US Department of Education, Washington, DC.

[13] Carnevale, A. P., Gainer, L. J., \& Meltzer, A. S. 1990. Workplace basics: The essential skills employers want. San Francisco: Jossey-Bass Publishers.

[14] Kyrieri, K.M. and Roidou, E. 2012. Satisfying Labour Demands in Mid- and Low-Skilled Occupations through Immigration. EIPAScope. 2012(1):37-42. ISSN 1025-6253

[15] The National Employers Skills Survey Main Report 2003. Retrieved August 28, 2015. from https:/www.gov.uk/government/uploads/system/uploads/att achment data/file/303643/2003national-employers-skills-sur vey-2003-key-findings.pdf

[16] Cotton, K. 1993. Developing Employability Skills. Northwest Regional Educational Laboratory.

[17] What Work Requires of Schools 2000. (1991, June) A SCANS Report for America. The Secretary's Commission on Achieving Necessary Skills, a publication of the US Department of Labor

[18] Diploma is no longer a key factor for employment. Round table. Zagreb 2013. Retrieved March 6, 2015. from http://liderpress.hr/poslovna-znanja/diploma-vise-nije-kljucn i-faktor/
[19] Employability Skills Report 2010. City and Guilds Centre for Skills Development, United kingdom

[20] Nunan, T. (1999, July 12-15). Graduate qualities, employment and mass higher education. HERDSA Annual Conference. Melbourne.

[21] Swiatek, J. 2000. Student and Employer Expectation, Proc. Of International Conference on Engineering Education (ICEE) Taiwan

[22] Yorke, M \& Knight, P. T. 2004. Embedding employability into the curriculum. Learning and Employability Series. LTSN Generic Centre

[23] Bracey, G. W. 2007. Growing an achievement gap. Education Week. 27(25): 26.

[24] Van Der Heijden, B., Boon, J., Van der Klink, M., \& Meijs, E. 2009). Employability enhancement through formal and informal learning: an empirical study among Dutch nonacademic university staff members. International journal of training and development. 13(1): 19-37.

[25] Nasir ANBMD, Ali FD, Noordin NKB, Noordin MSB. 2011. Technical skills and non-technical skills: predefinition concept. Proceedings of the IETEC'11 Conference, Kuala Lumpur, Malaysia.

[26] Fatoki, O. 2014. Final Year Undergraduate Students' Perception of their Non-technical Skills. Mediterrean Journal of Social Sciences. 5(7): 43-47.

[27] Hillage, J., \& Pollard, E. (1998). Employability: developing a framework for policy analysis. London: DfEE.

[28] Yorke, M. 2006. Employability in higher education: what it is - what it is not. Learning \& Employability Series one. The Higher Education Academy. York. United Kingdom.

[29] Griesel, H., \& Parker, B. 2009. Graduate attributes. Higher Education South Africa and the South African Qualifications Authority, Pretoria.

[30] Cox, S., \& King, D. 2006. Skill sets: an approach to embed employability in course design. Education \& Training, 48(4): 262-274.

[31] Buck, L. L., \& Barrick, R. K. 1987. They're Trained, But Are They Employable?. Vocational Education Journal. 62(5): 29-31.

[32] Watts, A. G. 2006. Career Development Learning and Employability. The Higher Education Academy, York.

[33] Bennett, N., Dunne, E., \& Carré, C. 1999. Patterns of core and generic skill provision in higher education. Higher education. 37(1): 71-93

[34] Dacre Pool, L. \& Sewell, P. 2007. The key to employability: developing a practical model of graduate employability. Education \& Training. 49(4): 277-289.

[35] Johnes, G. 2006. Career interruptions and labour market outcomes. EOC Working Paper Series, No. 45. Manchester: Equal Opportunities Commission.

[36] Harvey, L., Plimmer, L., Moon, S. \& Geall, V. 1997. Student Satisfaction Manual. Buckingham. Open University Press.

[37] Jones, C. \& English, J. 2004. A contemporary approach to entrepreneurship education. Education \& Training. 46(8/9): 416-423. 
[38] Rae, D. \& Carswell M. 2000. Using a life-story approach in researching entrepreneurial learning: The development of a conceptual model and its implications in the design of learning experiences. Education \& Training. 42(4/5): 220-228.

[39] Davies, L. 2000. Why kick the 'L' out of 'Learning'? The development of students' employability skills through part-time working. Education \& Training. 42(8): 436-444.

[40] Lindsay, C. 2002. Long-term unemployment and the employability gap: priorities for renewing Britain's new deal. Journal of European Industrial Training. 26(9): 411-419.

[41] Schulz, B. 2008. The Importance of Soft Skills: Education beyond academic knowledge. Journal of Language and Communication. 6: 146-154.
[42] Hopkins, C.D., Raymond, M.A., Carlson, L. 2011. Educating Students to Give Them a Sustainable Competitive Advantage. Journal of Marketing Education. 33(3): 337-347.

[43] Senge, P. 2000. A Fifth Discipline Resource: Schools that Learn. Doubleday New York. NY.

[44] Recommendation of the European Parliament and of the Council of 18 December 2006 on key competences for lifelong learning OJ L 394, 30.12.2006, p. 10-18 Retrieved August 24, 2015. fromhttp://eur-lex.europa.eu/legal-content/ EN/TXT/?uri=celex:32006H0962

[45] Wickramasinghe, V., \& Perera, L. 2010. Graduates', university lecturers' and employers' perceptions towards employability skills. Education \& Training. 52(3): 226-244. 